\title{
Fifty years of Cook Inlet beluga whale feeding ecology from isotopes in bone and teeth
}

\author{
Mark A. Nelson ${ }^{1,2,3, *}$, Lori T. Quakenbush ${ }^{3}$, Barbara A. Mahoney ${ }^{4}$, Brian D. Taras ${ }^{3}$, \\ Matthew J. Wooller ${ }^{1,2}$ \\ ${ }^{1}$ College of Fisheries and Ocean Sciences, University of Alaska Fairbanks, 905 N. Koyukuk Dr., Fairbanks, AK 99775, USA \\ ${ }^{2}$ Alaska Stable Isotope Facility, Water and Environmental Research Center, University of Alaska Fairbanks, \\ 306 Tanana Loop, Fairbanks, AK 99775, USA \\ ${ }^{3}$ Alaska Department of Fish and Game, 1300 College Road, Fairbanks, AK 99701, USA \\ ${ }^{4}$ Alaska Regional Office, National Marine Fisheries Service, National Oceanic and Atmospheric Administration, \\ 222 West $^{\text {th }}$ Ave., Anchorage, AK 99513-7577, USA
}

\begin{abstract}
Beluga whales Delphinapterus leucas that reside in Cook Inlet (CIBW) are important to coastal Alaska Native culture and subsistence, tourism, and ecologically as a top-level predator. Due to a $\sim 50 \%$ population decline in the 1990 s, the distinct population segment in Cook Inlet was designated depleted under the Marine Mammal Protection Act in 2000 and listed as endangered under the Endangered Species Act in 2008. Diet changes are a concern in CIBW lack of recovery, but beluga feeding ecology is difficult to study. Skulls from 20 CIBW and tooth growth layer groups (GLGs) from 26 individual CIBW showed decreasing trends for both nitrogen and carbon stable isotope ratios (expressed as $\delta^{15} \mathrm{~N}$ and $\delta^{13} \mathrm{C}$ values) from 1962 to 2007 . The decline in $\delta^{15} \mathrm{~N}$ values ( 1 to $2 \%$ ) could indicate a trophic level shift, but the magnitude of decline in $\delta^{13} \mathrm{C}$ values $(\sim 3 \%)$ is much greater ( $>5$ times greater) than expected for a trophic level shift. A shifted baseline or increased use of freshwater prey could explain the decline in $\delta^{13} \mathrm{C}$ values. We compared the strontium isotope composition $\left({ }^{87} \mathrm{Sr} /{ }^{86} \mathrm{Sr}\right.$ ratios) of GLGs with rivers that flow into Cook Inlet and used $\delta^{15} \mathrm{~N}$ values from the essential amino acid phenylalanine to determine that declining $\delta^{13} \mathrm{C}$ values may be explained by 2 scenarios: (1) CIBW foraged in the same location while the environmental isotopic baseline changed, or (2) CIBW foraged in a different location with a different baseline. This study presents the first evidence for a long-term ( 50 yr) change in CIBW feeding ecology.
\end{abstract}

KEY WORDS: Strontium $\cdot$ Carbon $\cdot$ Nitrogen $\cdot$ Dietary change $\cdot$ Delphinapterus leucas $\cdot$ Northern Gulf of Alaska

\section{INTRODUCTION}

The beluga whales Delphinapterus leucas in Cook Inlet (CIBW), Alaska, USA (Fig. 1), are isolated genetically (O'Corry-Crowe et al. 2002) and geographically (Hobbs et al. 2005, 2008, Rugh et al. 2010, Goetz et al. 2012, Shelden et al. 2015) from the other 4 beluga whale stocks in Alaska (Allen \& Angliss 2015). Aerial surveys, including those conducted by the National Marine Fisheries Service (NMFS), revealed

\footnotetext{
*Corresponding author: mark.nelson@alaska.gov
}

a decline in the CIBW population by $\sim 50 \%$ between 1994 (653 belugas) and 1998 (347 belugas; Hobbs et al. 2015). This decline was attributed to an unsustainable harvest estimated between 287 and 406 for those 5 yr (Mahoney \& Shelden 2000). In 1999, the harvest was greatly reduced, first by a temporary voluntary hunting moratorium and soon after by harvest regulations. CIBW were designated as depleted under the Marine Mammal Protection Act in 2000 (NOAA 2000) and listed as endangered under the

(c) The authors, and outside the USA, the US Government 2018. Open Access under Creative Commons by Attribution Licence. Use, distribution and reproduction are unrestricted. Authors and original publication must be credited.

Publisher: Inter-Research · www.int-res.com 


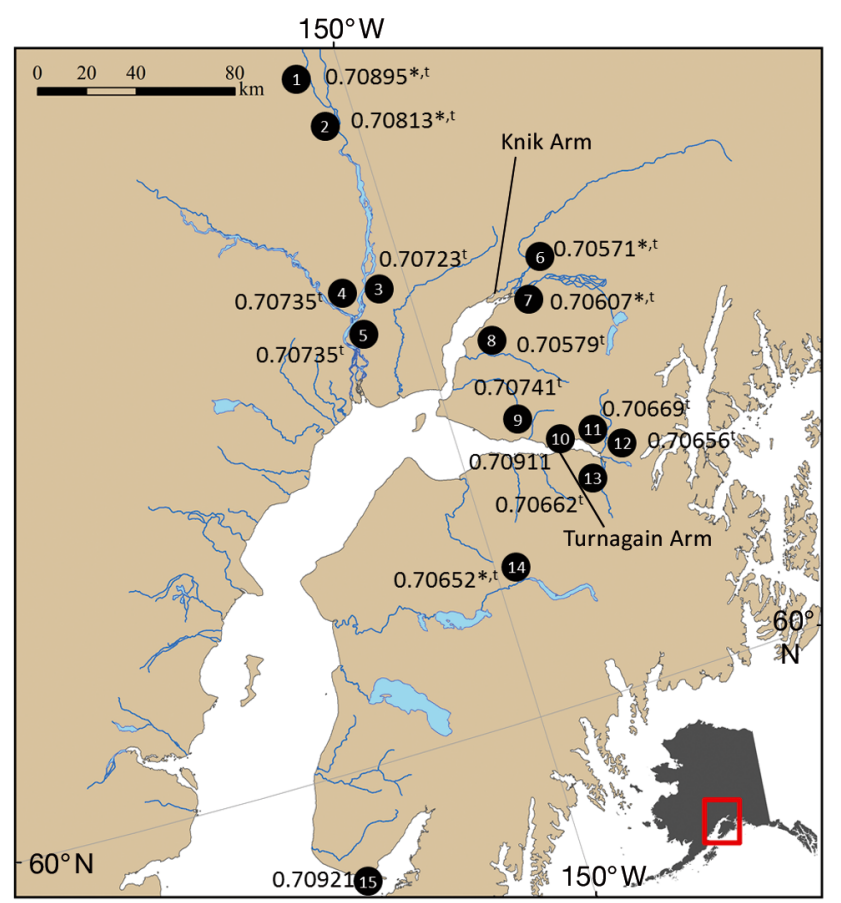

Fig. 1. Cook Inlet, Alaska, USA, with ${ }^{87} \mathrm{Sr} /{ }^{86} \mathrm{Sr}$ ratios marked from this study. Numbers in black circles correspond to the IDs in Table 1. Data from Brennan et al. (2014) are indicated by ' $*$ ', and superscript ' $t$ ' denotes weighted average ratio derived from samples taken in triplicate. Inset shows the location of Cook Inlet within Alaska

Endangered Species Act in 2008 (NOAA 2008). Critical habitat was then designated in 2011 (NOAA 2011), and a recovery plan was published in 2016 (NMFS 2016). CIBW were also classified as Critically Endangered under the IUCN Red List of Threatened Species in 2012 (Lowry et al. 2012).

CIBW have been hunted throughout recorded history by coastal Alaska Natives for food and cultural purposes (Huntington 2000, Mahoney \& Shelden 2000), and intermittently during the $20^{\text {th }}$ century by non-Natives for commercial and sporting purposes. Marine mammals were protected in 1972 when the Marine Mammal Protection Act was passed by Congress; however, an exemption allows the taking of marine mammals by coastal Alaska Natives, provided such taking is for subsistence purposes and conducted in a non-wasteful manner.

Five CIBW have been harvested since 1999: 1 in 2001, 2002, and 2003, and 2 in 2005 (Mahoney \& Shelden 2000). With the reduction in harvest, the CIBW population was predicted to increase, but instead, a slow (rate $\pm \mathrm{SE}:-0.4 \pm 1.3 \% \mathrm{yr}^{-1}$ ) decline occurred from 2004 to 2014 (NMFS 2016). During the documented population decline (1994-1999), the summer range of CIBW continued to contract into the upper reaches of Cook Inlet and shifted farther into the Knik and Turnagain Arms (Rugh et al. 2010, Shelden et al. 2015).

Although a range contraction may be the direct result of fewer animals requiring a smaller area, how it influences beluga feeding ecology is unknown. Increased concerns about CIBW susceptibility to potential threats within this restricted range (NMFS 2016) were summarized in the 2008 status review, which included catastrophic events, disease, predation, small population effects, noise, ship strikes, and decreased prey availability (Hobbs et al. 2008). The recovery plan examined these threats further and found that while the threat of a reduction in prey was of medium concern, little was known about prey availability and how availability has changed over time (NMFS 2016).

The diet of CIBW is mostly known from stomach contents of stranded and harvested animals (Quakenbush et al. 2015) and from subsistence hunter knowledge (Huntington 2000). CIBW summer prey is mainly seasonally available fish (e.g. eulachon Thaleichthys pacificus, Chinook salmon Oncorhynchus tshawytscha, chum salmon O. keta, and coho salmon $O$. kisutch) that enter Cook Inlet to spawn. Other fish prey available year-round include saffron cod Eleginus gracilis, walleye pollock Theragra chalcogramma, Pacific cod Gadus macrocephalus, starry flounder Platichthys stellatus, and yellowfin sole Limanda aspera. Invertebrates are also eaten, primarily shrimp from the families Caridea and Crangonidae along with worms (Polychaeta), shrimp-like amphipods (Crustacea), and Oregoniidae crabs (Huntington 2000, Hobbs et al. 2008, Quakenbush et al. 2015). Stomach contents of CIBW provide prey identifiable to species, but content analysis is limited to whales that die shortly after eating that are available for sampling. Because of these limitations, there were not enough CIBW stomachs available throughout the year or annually to provide information about whether CIBW diet has changed over time.

An alternative to directly studying the diet of CIBW is examining changes in prey availability over time; but this approach also proved to be of limited use for understanding changes in diet. Prey assemblages in the Gulf of Alaska have changed among warm (1947-1976), cold (1977-1997), and warm regimes (1998 to present) at a multi-decadal scale (Anderson \& Piatt 1999, Overland et al. 2008). Cold regimes produce more high-quality forage fish for birds and marine mammals than warm regimes (Anderson \& Piatt 1999). Little is known about how Cook Inlet prey assemblages are influenced by regime shifts in the Gulf of Alaska, but extensive closures of commercial 
shrimp, crab, and herring Clupea pallasii fisheries in lower Cook Inlet have occurred (Moore et al. 2000, Hollowell et al. 2016, Shields \& Dupuis 2017). Between the 1980s and 1990s, the coho salmon escapement increased, while Chinook, chum, and pink salmon O. gorbuscha declined, and sockeye salmon O. nerka remained fairly stable in the Susitna River drainage (Moore et al. 2000). However, total salmon escapement may not be an appropriate estimator to determine the number of salmon available for CIBW because escapement in a particular river does not equate to fish available as CIBW prey (Moore et al. 2000, Citta et al. 2016).

Isotopic analyses of hard tissues from belugas can provide general diet information integrated over long periods (e.g. bone integrates diet over $\geq 10$ yr) or short periods (e.g. a growth layer group from a tooth integrates an average diet of $1 \mathrm{yr}$ ), depending on how the tissue was formed and how it is maintained (turnover rate; Tieszen et al. 1983, Peterson \& Fry 1987, Newsome et al. 2010, Rioux et al. 2012, Witteveen et al. 2012, Waugh et al. 2018). We examined changes in CIBW feeding ecology and foraging location using nitrogen, carbon, and strontium isotope ratio data (expressed as $\delta^{15} \mathrm{~N}$ and $\delta^{13} \mathrm{C}$ values, and ${ }^{87} \mathrm{Sr} /{ }^{86} \mathrm{Sr}$ ratios) from bone ( $\delta^{15} \mathrm{~N}$ and $\delta^{13} \mathrm{C}$ values only), annual growth layer groups (GLGs) in teeth $\left(\delta^{15} \mathrm{~N}\right.$ and $\delta^{13} \mathrm{C}$ values, and ${ }^{87} \mathrm{Sr} /{ }^{86} \mathrm{Sr}$ ratios $)$, and water $\left({ }^{87} \mathrm{Sr} /{ }^{86} \mathrm{Sr}\right.$ ratios $)$ to determine if changes in CIBW feeding ecology had occurred during the last $50 \mathrm{yr} . \delta^{15} \mathrm{~N}$ and $\delta^{13} \mathrm{C}$ values can be used to detect changes in trophic level; for example, when a whale feeds a full trophic level higher, the isotopic value of its tissues increases for both $\delta^{15} \mathrm{~N}$ and $\delta^{13} \mathrm{C}$ by $\sim 3$ and $1 \%$, respectively (e.g. Peterson \& Fry 1987, Hobson et al. 1996, Kelly 2000, Newsome et al. 2009). $\delta^{13} \mathrm{C}$ values can also be used to determine if the carbon source of prey is marine or freshwater. For example, marine prey items often have higher $\delta^{13} \mathrm{C}$ values than freshwater prey (e.g. Tieszen et al. 1983, Peterson \& Fry 1987, Bentzen et al. 2007). ${ }^{87} \mathrm{Sr} /{ }^{86} \mathrm{Sr}$ ratios differ by geologic formation and influence the water in the rivers flowing through them (e.g. Brennan et al. 2014, 2015, Padilla et al. 2015), while marine waters are relatively uniform (Veizer 1989, Brennan et al. 2015), thus ${ }^{87} \mathrm{Sr} /{ }^{86} \mathrm{Sr}$ ratios can be used to determine the likely location within an estuarine system where prey or predators spent time. Another explanation to changing $\delta^{13} \mathrm{C}$ and $\delta^{15} \mathrm{~N}$ values is a change in the environmental baseline. Previous research has shown that the $\delta^{15} \mathrm{~N}$ value of phenylalanine retains a record of the $\delta^{15} \mathrm{~N}$ value at the base of the food chain with little fractionation (Chikaraishi et al. 2014, Yamaguchi \& McCarthy 2017). We therefore performed a pilot study to compare the $\delta^{15} \mathrm{~N}$ values of phenylalanine from individuals that died at the beginning of our record with those that died towards the end of the record. Through multiple lines of evidence, we will discuss how the feeding ecology of CIBW has changed over the past $50 \mathrm{yr}$.

\section{MATERIALS AND METHODS}

\section{Bone collagen extraction and preparation}

We extracted a small piece $(1 \mathrm{~cm} \times 5 \mathrm{~cm} \times 5 \mathrm{~cm})$ of bone from the zygomatic arch of 20 adult CIBW (8 males, 6 females, and 6 unknown) that died between 1964 and 2007 (Fig. 2a) and were archived at the University of Alaska Museum of the North (UAMN) in Fairbanks, Alaska, USA. The bone samples were cut out with a rotary tool and sanded to remove the outer cortex, and the clean solid bone was placed into a labeled glass culture tube. Each sample was then cleaned by: (1) rinsing twice with deionized water, (2) bathing for $1 \mathrm{~min}$ in a sonication bath, (3) soaking for $8 \mathrm{~h}$ in ethanol, (4) soaking for $8 \mathrm{~h}$ in methanol, (5) rinsing with deionized water, (6) soaking for $8 \mathrm{~h}$ in acetone, (7) rinsing with deionized water, (8) soaking twice for $8 \mathrm{~h}$ in chloroform and air drying under a fume hood, and (9) rinsing with deionized water (entire process modified from Matheus 1997). The cleaned bone was air-dried under a fume hood overnight and weighed. Demineralization occurred by covering the bone with water, adding 1.0 to $2.0 \mathrm{ml}$ of
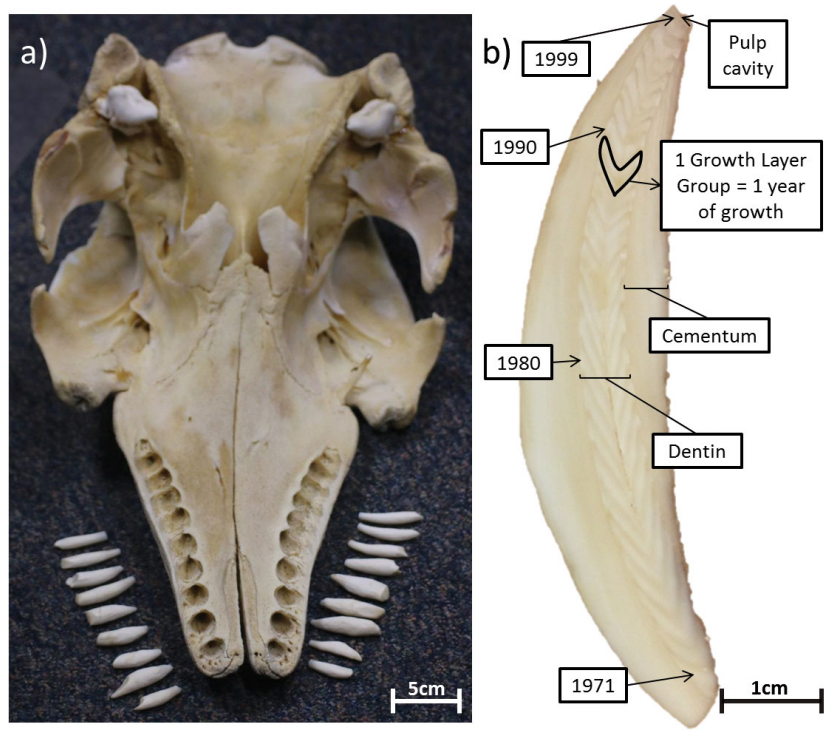

Fig. 2. (a) Skull of a Cook Inlet beluga whale (CIBW) and (b) CIBW tooth cut longitudinally to expose annual growth layer groups 
$6 \mathrm{~N}$ hydrochloric acid $(\mathrm{HCl})$, and refrigerating at $3^{\circ} \mathrm{C}$ for 12 to $24 \mathrm{~h}$. Once the solution stopped bubbling, it was decanted and rinsed with fresh deionized water, then recharged with fresh $\mathrm{HCl}$ and repeated until bubbling ceased. Typically this step took 7-10 d to completely demineralize the bone samples. Once demineralized, the sample was gelatinized with $\mathrm{HCl}$ at a $\mathrm{pH}$ of 3 to 4 and capped with helium to displace the air. The samples were then placed in a heating block that was kept at $65^{\circ} \mathrm{C}$ until the collagen dissolved, at which point the samples were then centrifuged for 3 to $6 \mathrm{~min}$ at $626 \times g$. The supernatant was passed through a filter, $50 \mathrm{~mm}$ in diameter with a pore size of $0.45 \mu \mathrm{m}$, and the filtrate collected in a scintillation vial, which was covered with a glass filter disk and freeze-dried (lyophilized) until only dry collagen remained. A 0.2 to $0.5 \mathrm{mg}$ sub-sample of each dried collagen sample was sealed in a tin capsule for stable carbon and nitrogen isotope analysis (described in the next subsection). A second sub-sample from 2 individuals that died in 1964 and 3 individuals that died after 2000 (see Table S6 in the Supplement at www.int-res.com/articles/suppl/ n036p077_supp.pdf) were used for analysis of the $\delta^{15} \mathrm{~N}$ values of phenylalanine following previously published protocols (Yamaguchi \& McCarthy 2017).

\section{Tooth collagen extraction and preparation}

Beluga teeth ( $\mathrm{n}=26$ teeth from individual whales: 14 males, 10 females, and 2 unknown; Fig. 2a), previously used to age the whales, were also analyzed for stable isotope composition. Bone from these 26 CIBW was analyzed for carbon and nitrogen isotope composition. A thin longitudinal section was cut from the center of each tooth, leaving 2 halves (Fig. 2b; Vos 2003). A micromill (ESI ${ }^{\circledR}$ New Wave ${ }^{\mathrm{TM}}$ Research) was used to remove dentin material along the selected GLG from one of the halves. A GLG was defined as a light and a dark layer of dentin (Vos 2003; our Fig. 2b) representing 1 yr of growth (Stewart et al. 2006, Waugh et al. 2018). GLGs integrating growth from whales 3 yr of age and younger were not used in this analysis to avoid diet signals associated with suckling (Newsome et al. 2010). Matthews \& Ferguson (2015) showed that 17 of 18 (94\%) belugas had been weaned during or before their third year.

The drilled powder from each GLG was collected with a small paintbrush into a microcentrifuge vial and demineralized by adding $0.25 \mathrm{~N} \mathrm{HCl}$ to cover the powder, which was then left overnight in a refrigerator. Samples were centrifuged at $2236 \times g$ for $5 \mathrm{~min}$ to concentrate the remaining powder at the bottom of the vial, and the liquid was pipetted off and discarded (Newsome et al. 2009). This was repeated until the white powder turned translucent, indicating that demineralization was complete. The samples were then rinsed with deionized water to remove $\mathrm{HCl}$, frozen, and freeze-dried until dry fluffy collagen remained $(\sim 10 \mathrm{~h})$. A 0.2 to $0.5 \mathrm{mg}$ sub-sample of the isolated collagen was sealed into a tin cup for isotope analysis.

\section{Stable nitrogen and carbon isotope analysis}

The $\delta^{15} \mathrm{~N}\left(\mathrm{n}=343\right.$ GLGs) and $\delta^{13} \mathrm{C}(\mathrm{n}=296$ GLGs $)$ values for bone collagen and tooth dentin samples were measured using a Costech ${ }^{\circledR}$ Elemental Analyzer coupled to a ThermoFisher Scientific ${ }^{\mathrm{TM}}$ Delta $V^{\mathrm{TM}}$ Isotope Ratio Mass Spectrometer. Stable isotope ratios are presented in delta $(\delta)$ notation:

$$
\delta X=\left(\frac{R_{\text {sample }}}{R_{\text {standard }}}-1\right) \times 1000
$$

where $R_{\text {sample }}$ is the ratio of the heavy to light isotope of the sample, and $R_{\text {standard }}$ is the ratio of the heavy to light isotope of the standards (i.e. atmospheric $\mathrm{N}_{2}$ for nitrogen and Vienna Pee Dee Belemnite for carbon). Analytical precision was validated by running a laboratory standard (peptone) after every 10 samples, and the standard deviation of these 71 analyses was $\leq 0.2 \%$ for both $\delta^{13} \mathrm{C}$ and $\delta^{15} \mathrm{~N}$ values. Increased burning of fossil fuels since the industrial revolution continues to alter the isotopic composition of $\mathrm{CO}_{2}$ in the atmosphere and the ocean, a phenomenon known as the Suess effect, which gradually lowers the baseline $\delta^{13} \mathrm{C}$ value over time (Francey et al. 1999). The baseline $\delta^{13} \mathrm{C}$ values decreased by $\sim 0.8 \%$ from 1960 to 2010 , and all $\delta^{13} \mathrm{C}$ values in this study were corrected for this effect following the approach described by Misarti et al. (2009). A 2-sample $t$-test was used to determine if $\delta^{13} \mathrm{C}$ and $\delta^{15} \mathrm{~N}$ values changed before and after 1995, and linear regression was used to determine how $\delta^{13} \mathrm{C}$ and $\delta^{15} \mathrm{~N}$ values trended over the entire study period.

\section{Collagen quality}

The quality of collagen from bone and teeth was evaluated by the atomic carbon to nitrogen ratio (C:N) calculated by the formula:

$$
\mathrm{C}: \mathrm{N}=\left(\frac{14}{12}\right) \times\left(\frac{\text { Concentration }(\%) \text { Carbon }}{\text { Concentration (\%) Nitrogen }}\right)
$$


All C:N ratios for bone were between 3.1 and 3.5 (Table S1 in the Supplement at www.int-res.com/ articles/suppl/n036p077_supp.pdf), indicating the collagen was of good quality (i.e. between 2.9 and 3.6; DeNiro et al. 1985, Ambrose 1990, Tatsch et al. 2016). C:N ratios from CIBW tooth dentin GLGs were between 3.1 and 5.7 (Table S2 in the Supplement). When a sample had a C:N ratio $\geq 3.6$, only its $\delta^{15} \mathrm{~N}$ data were used in further data analyses because C:N ratios higher than 3.6 indicate possibly compromised $\delta^{13} \mathrm{C}$ values (DeNiro et al. 1985, Ambrose 1990, Tatsch et al. 2016).

\section{Tooth dentin preparation and strontium isotope analysis}

A subset of GLGs $(n=44)$ from teeth analyzed for $\delta^{15} \mathrm{~N}$ and $\delta^{13} \mathrm{C}$ values in this study were selected for strontium isotope ratio $\left({ }^{87} \mathrm{Sr} /{ }^{86} \mathrm{Sr}\right)$ analyses using approximately $20 \mathrm{mg}$ of powdered dentin. GLGs that spanned 1968 to 2005 from 3 males and 2 females were analyzed (Table S5 in the Supplement). Of the 44 GLGs analyzed, 34 matched the GLGs (same GLG on same tooth) analyzed for $\delta^{15} \mathrm{~N}$ and $\delta^{13} \mathrm{C}$ values.

A ThermoFisher Scientific ${ }^{\mathrm{TM}}$, High Resolution Neptune $^{\mathrm{TM}}$ Multicollector-Inductively Coupled Plasma Mass Spectrometer housed at the University of Utah was used to analyze strontium samples, which had been purified for the ${ }^{87} \mathrm{Sr} /{ }^{86} \mathrm{Sr}$ analysis via an introduction system of aqueous solution using an inline chromatographic column (Mackey \& Fernandez 2011, Brennan et al. 2014). This solution method was also used to measure the ${ }^{87} \mathrm{Sr} /{ }^{86} \mathrm{Sr}$ ratios of water samples collected from the Cook Inlet region. Blanks or NIST standard reference material SRM987 were run between samples, and the mean $1 \mathrm{SE}$ was $<0.00001$ for all standard reference samples.

\section{Water collection and strontium isotope analysis}

Water samples were collected (in triplicate) from 8 freshwater rivers and 1 marine location (Turnagain Arm) in upper Cook Inlet and 1 marine location (Kachemak Bay) in the lower inlet during 27 May to 5 June 2016. Freshwater river samples were either collected above tidal influence (Susitna River, Yentna River, and Eagle River), or at low tide when access to areas above tidal influence was more difficult (Bird Creek, 20 Mile River, Portage Creek, and Placer River). Samples were collected for strontium isotope analysis following field collection methods described by Brennan et al. (2014), and sent via 2 d FedEx ${ }^{\circledR}$ to the Geochemistry Laboratory at the University of Utah, Salt Lake.

Mean ${ }^{87} \mathrm{Sr} /{ }^{86} \mathrm{Sr}$ ratios from water samples collected in triplicate were calculated by weighting each individual of the 3 values by their respective measurement error $(\mathrm{ME})$ :

Weighted triplicate mean $(\mathrm{TM})=\frac{\sum_{i=1}^{3}\left(\frac{1}{M E_{i}^{2}} \times S r_{i}\right)}{\sum_{i=1}^{3} \frac{1}{M E_{i}^{2}}}$

where $S r_{i}$ is the ${ }^{87} \mathrm{Sr} /{ }^{86} \mathrm{Sr}$ ratio from sample $i$ and $M E_{i}$ is the analytical ME from sample analysis from sample $i$.

Weighted SE of the triplicate was calculated as:

$$
\mathrm{SE}=\sqrt{\frac{\sum_{i=1}^{3}\left(\frac{1}{M E_{i}^{2}} \times\left(S r_{i}-\mathrm{TM}\right)^{2}\right)}{2 \sum_{i=1}^{3} \frac{1}{M E_{i}^{2}}} / 3}
$$

${ }^{87} \mathrm{Sr} /{ }^{86} \mathrm{Sr}$ ratios are presented as triplicate mean \pm 2 $\mathrm{SE}$, where SE is calculated as above for samples collected in triplicate. Samples not collected in triplicate are presented as ${ }^{87} \mathrm{Sr} /{ }^{86} \mathrm{Sr}$ ratios $\pm 2 \mathrm{ME}$.

\section{Statistical analysis}

Linear regressions were used to evaluate the isotopic signatures of CIBW bone collagen for temporal trends. The isotopic signatures $\left(\delta^{13} \mathrm{C}, \delta^{15} \mathrm{~N}\right.$, and ${ }^{87} \mathrm{Sr} /{ }^{86} \mathrm{Sr}$ ) of GLGs were also evaluated for temporal trends and the effect of sex using mixed-effects models appropriate for analyzing these repeated measures data. The random effect, or grouping variable, in these models is the individual beluga. Mixed-effects models were also used to explore the relationship between these isotopic signatures while controlling for the effect of sex. A set of candidate models was developed to test each hypothesis, and model selection was performed using likelihood ratio tests and Akaike's information criterion (AIC) for small sample sizes (AICc; Sugiura 1978, Hurvich \& Tsai 1989). Diagnostic tests were performed to evaluate model assumptions. $\mathrm{R}^{2}$ values were obtained using the r.squaredGLMM function in the R-package MuMIn (Bartoń 2018). This function is based on Nakagawa \& Schielzeth (2013), and its extension by Johnson (2014); marginal values are reported. In addition, an ANOVA was performed on the results from our pilot study to compare the $\delta^{15} \mathrm{~N}$ signature of phenylalanine between whales that died near the beginning of our study 
period with those that died toward the end. All analyses were carried out using Program R (R Core Team 2017).

\section{RESULTS}

The $\delta^{15} \mathrm{~N}$ and $\delta^{13} \mathrm{C}$ values of CIBW bone collagen generally declined over time (Fig. 3, Table S1 in the Supplement). Simple linear regressions indicated that $\delta^{15} \mathrm{~N}$ values declined at a rate $\pm \mathrm{SE}$ of $0.028 \pm$ $0.005 \%$ o $\mathrm{yr}^{-1}\left(\mathrm{R}^{2}=0.66, \mathrm{p}<0.001\right)$ and $\delta^{13} \mathrm{C}$ values declined at a rate \pm SE of $0.06 \pm 0.009 \% \mathrm{yr}^{-1}\left(\mathrm{R}^{2}=\right.$ 0.79, p < 0.001; Fig. 3).

The mean $\delta^{15} \mathrm{~N}$ value of phenylalanine from bones of CIBW that died in $1964(13.6 \pm 0.3 \%$ o) was significantly higher than from those that died after 2000 $(8.4 \pm 1.5 \%)$ at the $92 \%$ confidence level $(p=0.08$; Table S6). Therefore, the $\delta^{15} \mathrm{~N}$ value of the base of the food chain appears to have changed over the duration of this record.

Annual GLGs from CIBW teeth showed significant declines in $\delta^{15} \mathrm{~N}$ and $\delta^{13} \mathrm{C}$ values over time. The top mixed effects model in both cases included a random intercept term and correlated random slope for each animal. Random intercept and slope models allow for a separate line, each with its unique intercept and slope, to be fit to the data from each beluga. The top model is preferred over alternative models that call for either a common slope for all belugas or a common intercept. The effect of sex was not significant in either case $\left(p=0.13\right.$ for $\delta^{15} \mathrm{~N}$ and 0.28 for $\left.\delta^{13} \mathrm{C}\right)$. At the population level, $\delta^{15} \mathrm{~N}$ values ( $\mathrm{n}=343$ GLGs) decreased by $0.035 \pm 0.005 \%$ each year $(p<0.0001$, $\mathrm{R}^{2}=0.28$; Fig. 4a, Tables S2 \& S3 and Fig. S1), and $\delta^{13} \mathrm{C}$ values $(\mathrm{n}=296$ GLGs) decreased by $0.072 \pm$ $0.05 \%$ each year $\left(\mathrm{p}<0.0001, \mathrm{R}^{2}=0.63\right.$; Fig. $4 \mathrm{~b}$, Tables S2 \& S3, Fig. S2). Individual CIBW random effects for slope and intercept are listed in Table S3. Autocorrelation and partial autocorrelation functions applied to the residuals from simple linear regressions on individual whales showed no significant correlation, and we did not need to account for autocorrelation in the top model. ${ }^{87} \mathrm{Sr} /{ }^{86} \mathrm{Sr}( \pm 2 \mathrm{SE})$ ratios varied across the sample locations in the Cook Inlet watershed (Fig. 1, Table 1, Table S4). The highest ${ }^{87} \mathrm{Sr} /{ }^{86} \mathrm{Sr}$ ratio was found in Kachemak Bay (near Homer Spit), in lower Cook Inlet (site 15, Fig. 1, Table 1, Table S4) and was equivalent to the global marine ratio $(0.70918 \pm 0.00006$; Brennan et al. 2015). The second highest ${ }^{87} \mathrm{Sr} /{ }^{86} \mathrm{Sr}$ ratio was also from marine waters in Turnagain Arm in upper Cook Inlet (site 10, Fig. 1, Table 1, Table S4).

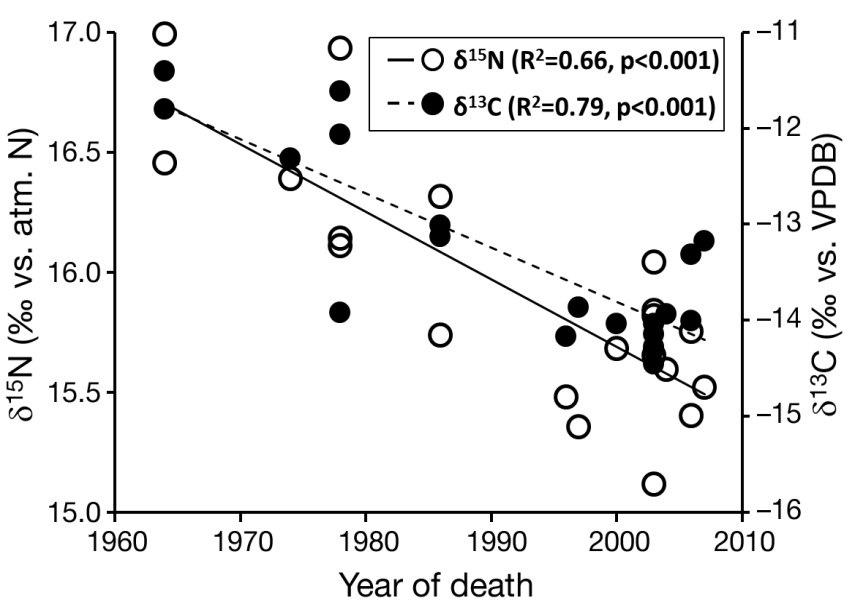

Fig. 3. $\delta^{15} \mathrm{~N}$ and $\delta^{13} \mathrm{C}$ values from Cook Inlet beluga bone collagen (skulls) plotted against year, showing regression (linear) lines for both; atm. N: atmospheric nitrogen, VPDB:

Vienna Pee Dee belemnite
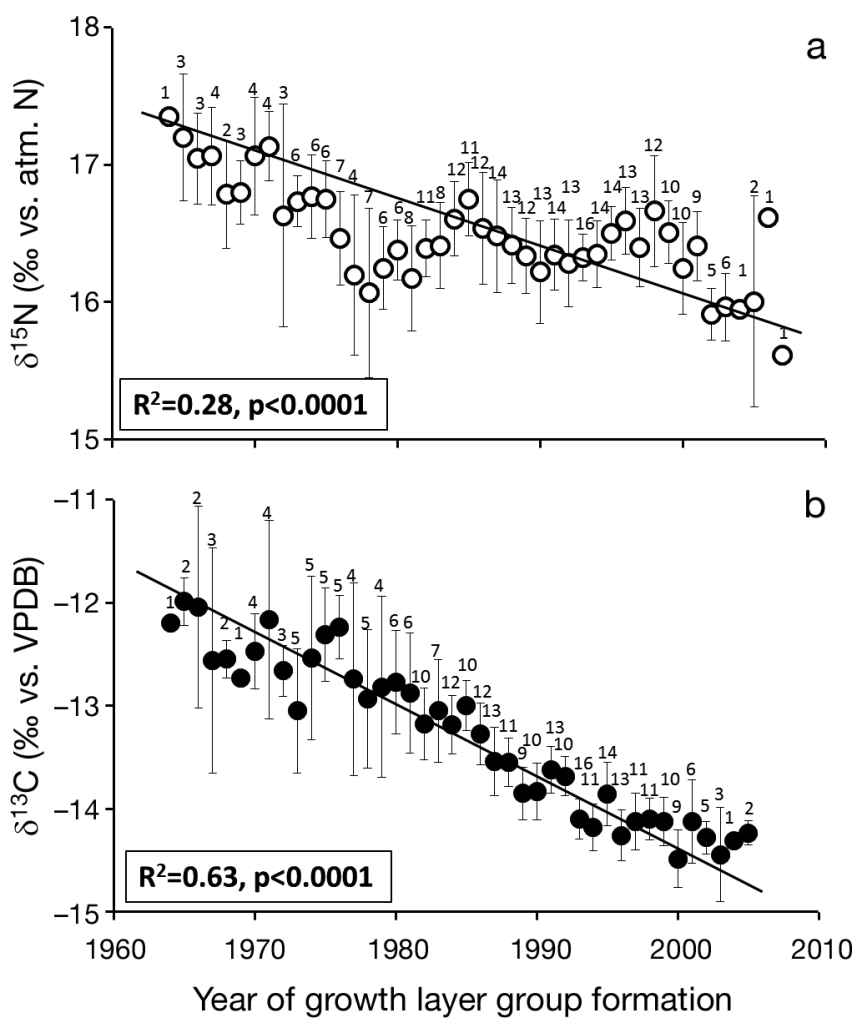

Fig. 4. Mean ( \pm 2 SE) (a) $\delta^{15} \mathrm{~N}$ and (b) $\delta^{13} \mathrm{C}$ values from Cook Inlet beluga tooth growth layer groups (GLGs) plotted by year of formation. The fitted line in each case is the population level trend from the top mixed-effects model. (Refer to Tables S2 \& S3 and Figs. S1 \& S2 in the Supplement for time series data and trend lines for individual belugas in addition to the population level trend line.) The number above each mean value represents the number of GLGs that make up that mean value; atm. N: atmospheric nitrogen, VPDB: Vienna Pee Dee belemnite 
Table 1. Summary of ${ }^{87} \mathrm{Sr} /{ }^{86} \mathrm{Sr}$ ratios from Cook Inlet rivers and marine waters, including date and location of sampling sites. ID matches the ID used in Fig. 1. Data from Brennan et al. (2014) are indicated by *; average ratios and the standard error (SE) from triplicate samples, indicated by a superscript ' $t$,' are weighted by the SE from analysis in the present study

\begin{tabular}{|llccccc|}
\hline ID & $\begin{array}{l}\text { Date } \\
\text { collected }\end{array}$ & Waterbody & $\begin{array}{c}\text { Latitude } \\
\left({ }^{\circ} \mathrm{N}\right)\end{array}$ & $\begin{array}{c}\text { Longitude } \\
\left({ }^{\circ} \mathrm{W}\right)\end{array}$ & ${ }^{87} \mathrm{Sr} /{ }^{86} \mathrm{Sr}$ & $\pm 2 \mathrm{SE}$ \\
\hline $1^{*, \mathrm{t}}$ & 11-Sep-10 & Chulitna R. & 62.568 & 150.236 & 0.708948 & 0.000042 \\
$2^{*, \mathrm{t}}$ & 11-Sep-10 & Susitna R. & 62.178 & 150.172 & 0.708127 & 0.000057 \\
$3^{\mathrm{t}}$ & 27-May-16 & Susitna R. & 61.588 & 150.410 & 0.707232 & 0.000039 \\
$4^{\mathrm{t}}$ & 27-May-16 & Yentna R. & 61.608 & 150.508 & 0.707349 & 0.000011 \\
$5^{\mathrm{t}}$ & 27-May-16 & Susitna R. & 61.533 & 150.545 & 0.707353 & 0.000074 \\
$6^{*, \mathrm{t}}$ & 14-Sep-10 & Matanuska R. & 61.734 & 148.765 & 0.705711 & 0.000013 \\
$7^{*, \mathrm{t}}$ & 14-Sep-10 & Knik R. & 61.476 & 148.876 & 0.706074 & 0.000075 \\
$8^{\mathrm{t}}$ & 2-Jun-16 & Eagle R. & 61.309 & 149.574 & 0.705793 & 0.000020 \\
$9^{\mathrm{t}}$ & 2-Jun-16 & Bird Cr. & 60.973 & 149.467 & 0.707406 & 0.000050 \\
10 & 5-Jun-16 & Turnagain Arm & 60.937 & 149.265 & 0.709110 & 0.000021 \\
$11^{\mathrm{t}}$ & 2-Jun-16 & 20 Mile R. & 60.845 & 148.989 & 0.706692 & 0.000014 \\
$12^{\mathrm{t}}$ & 2-Jun-16 & Portage Cr. & 60.827 & 148.977 & 0.706558 & 0.000041 \\
$13^{\mathrm{t}}$ & 2-Jun-16 & Placer R. & 60.817 & 148.988 & 0.706623 & 0.000005 \\
$14^{*, \mathrm{t}}$ & 12-Sep-10 & Kenai R. & 60.487 & 149.935 & 0.706517 & 0.000012 \\
15 & 2-Jun-16 & Lower Cook Inlet & 59.606 & 151.436 & 0.709206 & 0.000028 \\
\hline
\end{tabular}

toward the more freshwater signature of Turnagain Arm (0.70911; Fig. 5). The top model included a random intercept term for each animal, the variable sex, and the interaction of sex and year. Two of the 3 males were displaced to lower ${ }^{87} \mathrm{Sr} /$ ${ }^{86} \mathrm{Sr}$ ratios than the waters of Lower Cook Inlet, while the 2 females not only had lower mean ${ }^{87} \mathrm{Sr} /{ }^{86} \mathrm{Sr}$ values, but they also showed a trend of decreasing values with time (1982 to 1997 and 1991 to 2005). For males, the slope \pm SE which was $-1.749 \times 10^{-7} \pm 7.507 \times 10^{-7}$ was not significantly different from 0 , while that for females $(-2.258 \times$ $10^{-6} \pm 4.728 \times 10^{-7}$ ) was significant and had $\mathrm{R}^{2}=0.63$.

We also examined the correlation between ${ }^{87} \mathrm{Sr} /{ }^{86} \mathrm{Sr}$ ratios with $\delta^{15} \mathrm{~N}$ and $\delta^{13} \mathrm{C}$ values from the same

The ${ }^{87} \mathrm{Sr} /{ }^{86} \mathrm{Sr}$ ratios of all rivers tested in this study were lower than the marine values; the highest was from Bird Creek (site 9, Fig. 1) and the lowest was from Eagle River (site 8, Fig. 1, Table 1, Table S4).

${ }^{87} \mathrm{Sr} /{ }^{86} \mathrm{Sr}$ ratios of 44 GLGs in teeth from 5 CIBW teeth ( 3 males, 2 females) trended away from the marine signature in Lower Cook Inlet (0.70921)
GLGs on the same tooth ( $\mathrm{n}=34$ GLGs), and neither pairing was significantly correlated ( $p=0.10$ for $\delta^{15} \mathrm{~N}$ and $p=0.95$ for $\delta^{13} \mathrm{C}$ ). However, sex was significant in both cases $\left(p=0.0001\right.$ for $\delta^{15} \mathrm{~N}$ and $p=0.0008$ for $\left.\delta^{13} \mathrm{C}\right)$. In addition to sex, the top models included a random intercept for each animal and a common slope.

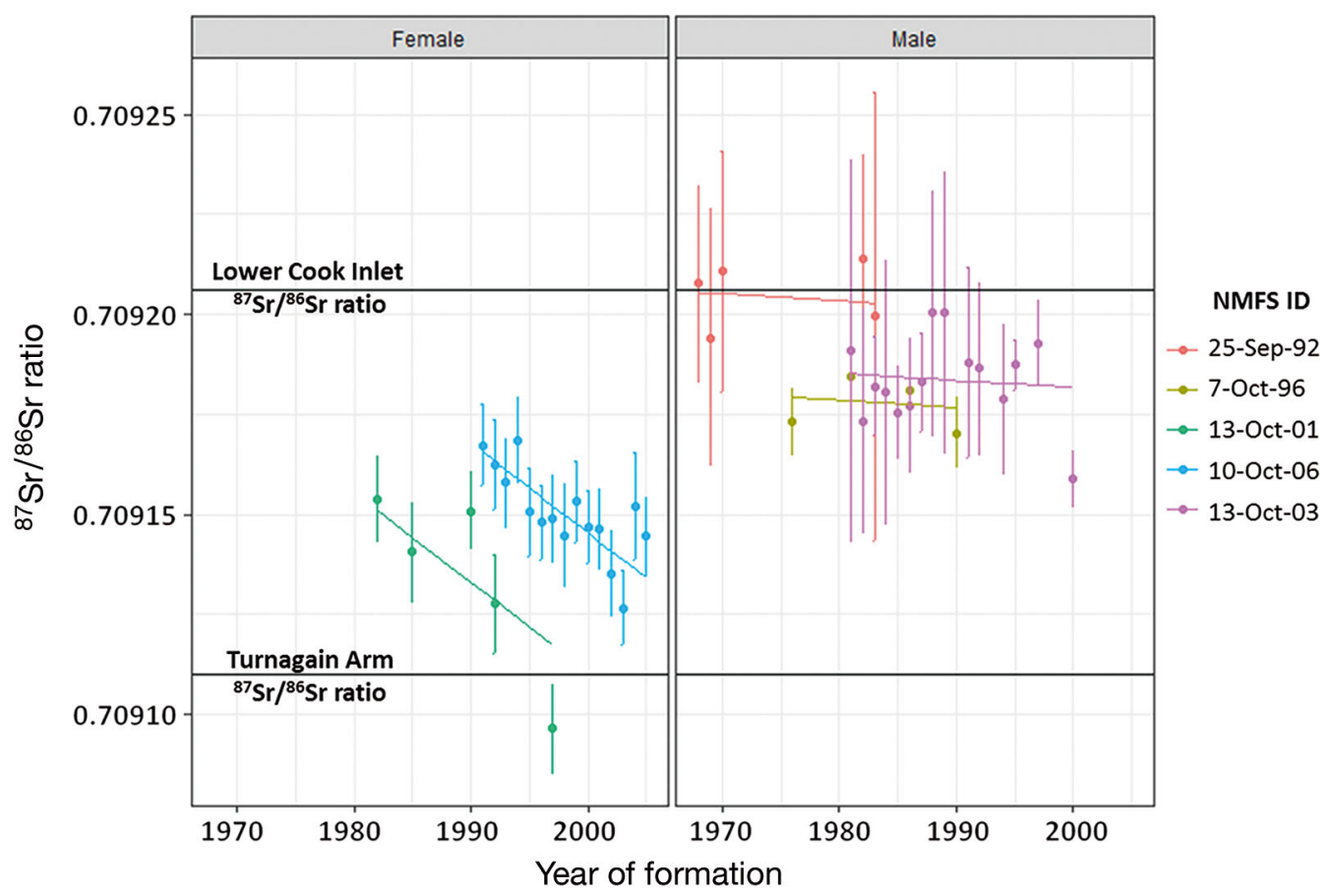

Fig. $5 .{ }^{87} \mathrm{Sr} /{ }^{86} \mathrm{Sr}$ ratios from Cook Inlet beluga growth layer groups (GLGs) by year of formation 


\section{DISCUSSION}

Stable isotope ratios preserved in CIBW bone and GLGs from CIBW teeth integrate the isotopic composition of beluga diet. In this study, we analyzed samples representing the period from the 1950s to 2007. Bone metabolism involves removing old material (made with diet items of the past) by osteoclasts and secreting new material (made with diet items available currently) via osteoblasts at a very slow rate (2 to $\left.3 \% \mathrm{yr}^{-1}\right)$, such that bone integrates dietary isotopes for at least $10 \mathrm{yr}$ and possibly for the lifetime (Clarke 2008). In contrast, GLGs remain biochemically unchanged after they are formed and, because belugas form $1 \mathrm{GLG} \mathrm{yr}^{-1}$, the isotopes in each GLG integrated diet for $1 \mathrm{yr}$ of a beluga's life (Stewart et al. 2006, Luque et al. 2007). Both $\delta^{15} \mathrm{~N}$ and $\delta^{13} \mathrm{C}$ values from CIBW declined during our study period (1950s to 2007) in both bone and teeth, providing definitive evidence that a change in CIBW feeding ecology occurred. For a full decrease in trophic level we would expect $\delta^{15} \mathrm{~N}$ values to decline by $\sim 3 \%$ and $\delta^{13} \mathrm{C}$ values to decline by $\sim 1 \%$ (Peterson \& Fry 1987). However, our data showed less than a full trophic level decline for $\delta^{15} \mathrm{~N}(\sim 1$ to $2 \%)$ and more than a trophic level decline for $\delta^{13} \mathrm{C}(\sim 3 \%$; Fig. 4).

Declining $\delta^{15} \mathrm{~N}$ and $\delta^{13} \mathrm{C}$ values could represent a change in prey source (Peterson \& Fry 1987). However, a change in $\delta^{15} \mathrm{~N}$ and $\delta^{13} \mathrm{C}$ values of the baseline, primary production in the environment can also occur over time (Schell 2000, Post 2002, Christensen \& Richardson 2008, Casey \& Post 2011, Marcoux et al. 2012). Because of the documented range contraction from more marine areas, middle and lower Cook Inlet, to more freshwater-influenced areas in upper Cook Inlet (Rugh et al. 2010), we suspected the decline in $\delta^{13} \mathrm{C}$ values indicated a change from a marine prey base to a more freshwater-influenced prey base.

To test if the declining $\delta^{13} \mathrm{C}$ values indicated a change to more freshwater prey, we used isotopes of a third element, strontium. Fish exchange water passively over gills, and their internal ${ }^{87} \mathrm{Sr} /{ }^{86} \mathrm{Sr}$ ratio reflects their surroundings (Brennan et al. 2014, Padilla et al. 2015). Beluga whales are not known to drink water, but rather receive their metabolic water, and thus strontium, from their prey. When prey is consumed, strontium is incorporated into hard structures, such as bone and teeth, because of its similarity to calcium (Britton et al. 2009). Because ${ }^{87} \mathrm{Sr} /{ }^{86} \mathrm{Sr}$ ratios are driven by geologic processes, the ratio of ${ }^{87} \mathrm{Sr} /{ }^{86} \mathrm{Sr}$ in a river's water remains relatively unchanged at a specific site through time, but varies along the length of the river as a result of the geologic formation the river flows through. The magnitude of variation in terms of ${ }^{87} \mathrm{Sr} /{ }^{86} \mathrm{Sr}$ in ocean waters is considerably lower compared to the ${ }^{87} \mathrm{Sr} /{ }^{86} \mathrm{Sr}$ variation exhibited by the rivers and estuaries in Alaska (Bataille et al. 2014, Brennan et al. 2014, 2015). Therefore, ${ }^{87} \mathrm{Sr} /{ }^{86} \mathrm{Sr}$ ratios measured in the hard structures of an organism can be compared to the ${ }^{87} \mathrm{Sr} /{ }^{86} \mathrm{Sr}$ ratios of various estuarine and freshwater sources, and used to determine when an organism switches from a marine-influenced prey to a more freshwater-influenced prey. In some cases, the ${ }^{87} \mathrm{Sr} /$ ${ }^{86} \mathrm{Sr}$ ratio can identify the source (river) of freshwater prey.

We compared ${ }^{87} \mathrm{Sr} /{ }^{86} \mathrm{Sr}$ ratios and $\delta^{13} \mathrm{C}$ values from the same GLG on the same tooth for 5 whales (representing diet from 1968 to 2005) to determine whether a change in CIBW diet to a more freshwater-influenced prey was indicated. Although we found no correlation between ${ }^{87} \mathrm{Sr} /{ }^{86} \mathrm{Sr}$ ratios and $\delta^{13} \mathrm{C}$ values $(\mathrm{p}=$ 0.78 ), we did find that ${ }^{87} \mathrm{Sr} /{ }^{86} \mathrm{Sr}$ ratios trended away from the global marine ratio towards a more freshwater signal. Fig. 5 shows a significant declining trend of ${ }^{87} \mathrm{Sr} /{ }^{86} \mathrm{Sr}$ values in the 2 females sampled, but not in the 3 males sampled. The declining trend in females and displacement in males most likely represent a dietary change from marine to more freshwater prey. Although this analysis is sufficient for proposing a hypothesis regarding differences between the sexes, the sample size is too small to draw conclusive population-level inferences. It is notable that these changes in foraging ecology occurred while the range of CIBW continued to contract into the upper reaches of Cook Inlet (Rugh et al. 2010), where freshwater prey items are available. To determine which freshwater input was most influential, we compared the ${ }^{87} \mathrm{Sr} /{ }^{86} \mathrm{Sr}$ ratio from GLGs to known ratios in river systems flowing into Cook Inlet available from Brennan et al. (2014) and from the present study (Fig. 1). Although we were not able to definitively identify which river(s) influenced CIBW the most, the recent lower ${ }^{87} \mathrm{Sr} /{ }^{86} \mathrm{Sr}$ ratios indicate that CIBW are now feeding on prey that is more influenced by freshwater.

Our carbon and nitrogen isotope data could indicate a change in CIBW feeding ecology, and the strontium data indicate a change towards a more freshwater-influenced diet; however, whether these changes could also be explained by an environmental change in baseline was unknown. Therefore, we analyzed the $\delta^{15} \mathrm{~N}$ values of the amino acid phenylalanine from 5 bone collagen samples from CIBW that died during 1964 ( 2 whales) and after 2000 (3 whales). 
Phenylalanine is an essential amino acid (i.e. not manufactured by organisms other than primary producers or altered along the food chain) and the $\delta^{15} \mathrm{~N}$ values of this amino acid have been used to identify the $\delta^{15} \mathrm{~N}$ value at the base of food chains (e.g. Chikaraishi et al. 2014). Because the mean $\delta^{15} \mathrm{~N}$ value of phenylalanine from beluga whales that died more recently (after 2000) was lower than those that died at the beginning of our study period (during 1964; Table S6), the $\delta^{15} \mathrm{~N}$ value of the base of the food chain sustaining CIBW has changed over the duration of this record. Further analyses would be beneficial to strengthen this compound-specific analysis; however, a change in the isotopic $(\mathrm{N})$ composition of the base of their food chain could result from 3 scenarios: (1) CIBW have foraged in a similar location through time and the $\delta^{15} \mathrm{~N}$ value of the base of the food chain decreased at that location, (2) CIBW now forage in a different location that has a $\delta^{15} \mathrm{~N}$ value at the base of the food chain that is lower than at the prior location, or (3) a combination of the first 2 scenarios.

The ${ }^{87} \mathrm{Sr} /{ }^{86} \mathrm{Sr}$ results, especially when interpreted in the context of range contraction, indicate a change in foraging to areas with fresher water, thus ruling out scenario 1 in favor of scenarios 2 or 3 . A change in CIBW distribution to greater use of the upper inlet was documented over 3 periods: 1978-1979, 19931997, and 1998-2008 (Rugh et al. 2010). This change in location puts CIBW in closer proximity to freshwater and likely to prey influenced by freshwater. Indeed, we suspect the decline in $\delta^{13} \mathrm{C}$ values indicates a change from a marine prey base to a more freshwater-influenced prey base. Lower ${ }^{87} \mathrm{Sr} /{ }^{86} \mathrm{Sr}$ ratios demonstrate greater freshwater influence in foraging ecology, and the change in isotopic (N) composition of the amino acid phenylalanine also supports a shifted baseline that could be explained by a shift towards more freshwater prey. Based on our complete data set (including declining $\delta^{15} \mathrm{~N}$ and $\delta^{13} \mathrm{C}$ values in bone and teeth, lower ${ }^{87} \mathrm{Sr} /{ }^{86} \mathrm{Sr}$ ratios in teeth, and lower $\delta^{15} \mathrm{~N}$ values in phenylalanine from teeth) and previous survey findings (Rugh et al. 2010), we consider the most likely explanation to be scenario 2 from above or scenario 3, a combination of both scenarios, that CIBW now forage in a different location (upper Cook Inlet) with a different $\delta^{15} \mathrm{~N}$ value at the base of the food chain than in the base at the previous forage location. Our isotope data are consistent with more freshwater-influenced prey through time, the $\delta^{13} \mathrm{C}$ data (bone and GLGs) indicate that the change in foraging behavior began at least as far back as the $1950 \mathrm{~s}$, and the ${ }^{87} \mathrm{Sr} /{ }^{86} \mathrm{Sr}$ ratio data indicate that the change in females has occurred since at least 1982 (Figs. 4 \& 5). More data are necessary to better determine when these changes began and if they are continuing, but both data sets indicate that the shift began long before the documented population decline in the 1990s. Therefore, if this change in habitat and prey is related to the decline in CIBW abundance, then we must look farther back in time (i.e. before the documented decline in the 1990s) to determine what was responsible for the greater freshwater influence in CIBW feeding ecology.

If changes in prey populations are responsible for the change in feeding ecology, we could evaluate changes in prey availability. Decreases in shrimp, $\mathrm{crab}$, and some fish including herring and salmon (chinook, chum, and pink) over the last few decades have been documented, but determining whether declines in prey abundance correspond to declining CIBW foraging opportunities is difficult to measure (Moore et al. 2000, Hollowell et al. 2016, Shields \& Dupuis 2017).

The ${ }^{87} \mathrm{Sr} /{ }^{86} \mathrm{Sr}$ ratio data from GLGs indicate that female CIBW were increasingly feeding on more freshwater-influenced prey through their lifetime, while the males, although displaced towards a more freshwater signature, showed no trend through time (Fig. 5). This difference in ${ }^{87} \mathrm{Sr} /{ }^{86} \mathrm{Sr}$ ratios between sexes was not seen in the $\delta^{15} \mathrm{~N}$ and $\delta^{13} \mathrm{C}$ values, but could indicate a sex-specific foraging strategy. Citta et al. (2016) found that female beluga whales in Bristol Bay spent more time in areas where pink salmon were more abundant, possibly to allow more foraging opportunities for their calves. Beluga whales do not break apart or chew their prey; therefore, prey size is limited by what they can swallow whole, which likely makes larger salmon unavailable to smaller female belugas and their calves. If CIBW exhibit a similar sex-specific foraging strategy, this could explain the differences detected in ${ }^{87} \mathrm{Sr} /{ }^{86} \mathrm{Sr}$ ratios between males and females. It is still unclear, however, why the difference in foraging was detected in ${ }^{87} \mathrm{Sr} /{ }^{86} \mathrm{Sr}$ ratios but not in the $\delta^{15} \mathrm{~N}$ and $\delta^{13} \mathrm{C}$ values.

Additional research using strontium isotopes (e.g. more water sample locations, GLGs representing more recent years) and carbon and nitrogen isotopes are necessary to better understand the changes we identified in this study. Additionally, further study of phenylalanine would be beneficial to better determine how the baseline has changed and to better understand the different behaviors between males and females. Our data provide evidence of a longterm shift to more freshwater-influenced feeding habitat and ecology. How this behavior relates to the continued decline in CIBW or their possible recovery, however, remains unknown. 
Acknowledgements. We are grateful for the funding that was made available by NMFS, Alaska Region, and through the Northern Gulf of Alaska Applied Research Award (May 2015). CIBW skulls and teeth were made available by UAMN, and other teeth were made available by NMFS. Samples were analyzed at the Alaska Stable Isotope Facility $\left(\delta^{15} \mathrm{~N}\right.$ and $\delta^{13} \mathrm{C}$ values) and the Geochemistry Laboratory at the University of Utah, Salt Lake (87Sr/86Sr ratios), with assistance from Tim Howe, Norma Haubenstock, and Diego Fernandez. The micromill for micro-sampling GLGs was made available by Dr. Kenneth Severin and Karen Spaleta in the Advanced Instrumentation Laboratory at the University of Alaska Fairbanks. Justin Crawford produced the map in Fig. 1. Research was conducted under NMFS research permits 932-1905/MA-009526, 18727, and 17410. Reference to any specific commercial products, process, or service by trade name, trademark, manufacturer, or otherwise, does not necessarily constitute or imply its endorsement, recommendation, or favoring by the United States Government or the State of Alaska.

\section{LITERATURE CITED}

Allen BM, Angliss RP (2015) Alaska marine mammal stock assessments, 2014. Tech Memo NMFS-AFSC-301. US Department of Commerce, NOAA, Seattle, WA

Ambrose SH (1990) Preparation and characterization of bone and tooth collagen for isotopic analysis. J Archaeol Sci 17:431-451

Anderson PJ, Piatt JF (1999) Community reorganization in the Gulf of Alaska following ocean climate regime shift. Mar Ecol Prog Ser 189:117-123

Bartoń K (2016) MuMIn: Multi-model inference. R package version 1.40.4. https://CRAN.R-project.org/package=Mu MIn

Bataille CP, Brennan SR, Hartmann J, Moosdorf N, Wooller MJ, Bowen GJ (2014) A geostatistical framework for predicting variability in strontium concentrations and isotope ratios in Alaskan rivers. Chem Geol 389:1-15

Bentzen TW, Follmann EH, Amstrup SC, York GS, Wooller MJ, O'Hara TM (2007) Variation in winter diet of southern Beaufort Sea polar bears inferred from stable isotope analysis. Can J Zool 85:596-608

Brennan SR, Fernandez DP, Mackey G, Cerling TE, Bataille CP, Bowen GJ, Wooller MJ (2014) Strontium isotope variation and carbonate versus silicate weathering in rivers from across Alaska: implications for provenance studies. Chem Geol 389:167-181

* Brennan SR, Zimmerman CE, Fernandez DP, Cerling TE, McPhee MV, Wooller MJ (2015) Strontium isotopes delineate fine-scale natal origins and migration histories of Pacific salmon. Sci Adv 1:e1400124

Britton K, Grimes V, Dau J, Richards MP (2009) Reconstructing faunal migrations using intra-tooth sampling and strontium and oxygen isotope analyses: a case study of modern caribou (Rangifer tarandus granti). J Archaeol Sci 36:1163-1172

Casey MM, Post DM (2011) The problem of isotopic baseline: reconstructing the diet and trophic position of fossil animals. Earth Sci Rev 106:131-148

Chikaraishi Y, Steffan SA, Ogawa NO, Ishikawa NF, Sasaki Y, Tsuchiya M, Ohkouchi N (2014) High-resolution food webs based on nitrogen isotopic composition of amino acids. Ecol Evol 4:2423-2449
Christensen JT, Richardson K (2008) Stable isotope evidence of long-term changes in the North Sea food web structure. Mar Ecol Prog Ser 368:1-8

C Citta JJ, Quakenbush L, Frost KJ, Lowry L, Hobbs RC, Aderman H (2016) Movements of beluga whales (Delphinapterus leucas) in Bristol Bay, Alaska. Mar Mamm Sci 32:1272-1298

Clarke B (2008) Normal bone anatomy and physiology. Clin J Am Soc Nephrol 3:S131-S139

* DeNiro MJ, Schoeninger MJ, Hastorf CA (1985) Effect of heating on the stable carbon and nitrogen isotope ratios of bone collagen. J Archaeol Sci 12:1-7

Francey RJ, Allison CE, Etheridge DM, Trudinger CM and others (1999) A 1000-year high precision record of $\delta^{13} \mathrm{C}$ in atmospheric $\mathrm{CO}_{2}$. Tellus 51:170-193

* Goetz KT, Montgomery RA, Ver Hoef JM, Hobbs RC, Johnson DS (2012) Identifying essential summer habitat of the endangered beluga whale Delphinapterus leucas in Cook Inlet, Alaska. Endang Species Res 16:135-147

Hobbs RC, Laidre KL, Vos DJ, Mahoney BA, Eagleton M (2005) Movements and area use of belugas, Delphinapterus leucas, in a subarctic Alaskan estuary. Arctic 58:331-340

Hobbs RC, Shelden KEW, Rugh DJ, Norman SA (2008) 2008 Status review and extinction risk assessment of Cook Inlet belugas (Delphinapterus leucas). AFSC Proc Rep 2008-02. Alaska Fisheries Science Center, National Marine Fisheries Service, NOAA, Seattle, WA

* Hobbs RC, Shelden KEW, Rugh DJ, Sims L, Waite JM (2015) Estimated abundance and trend in aerial counts of beluga whales, Delphinapterus leucas, in Cook Inlet, Alaska, 1994-2012. Mar Fish Rev 77:11-31

*Hobson KA, Schell DM, Renouf D, Noseworthy E (1996) Stable carbon and nitrogen isotopic fractionation between diet and tissues of captive seals: implications for dietary reconstructions involving marine mammals. Can J Fish Aquat Sci 53:528-533

Hollowell G, Otis E, Ford E (2016) 2015 Lower Cook Inlet area finfish management report. Alaska Department of Fish and Game, Division of Commercial Fisheries, Anchorage, AK

Huntington HP (2000) Traditional knowledge of the ecology of belugas, Delphinapterus leucas, in Cook Inlet, Alaska. Mar Fish Rev 62:134-140

*Hurvich CM, Tsai CL (1989) Regression and time series model selection in small samples. Biometrika 76 : 297-307

Johnson PCD (2014) Extension of Nakagawa \& Schielzeth's $\mathrm{R}^{2}{ }_{\text {GLMM }}$ to random slopes models. Methods Ecol Evol 5: 944-946

Kelly JF (2000) Stable isotopes of carbon and nitrogen in the study of avian and mammalian trophic ecology. Can J Zool 78:1-27

* Lowry L, O'Corry-Crowe G, Goodman D (2012) Delphinapterus leucas (Cook Inlet subpopulation). The IUCN Red List of Threatened Species 2012: e.T61442A17691385 http://dx.doi.org/10.2305/IUCN.UK.2017-3.RLTS.T6335A 50352346.en

Luque SP, Higdon JW, Ferguson SH (2007) Dentine deposition rates in belugas (Delphinapterus leucas): an analysis of the evidence. Aquat Mamm 33:241-245

Mackey GN, Fernandez DP (2011) High throughput Sr isotope analysis using an automated column chemistry system. American Geophysical Union, Fall Meeting 2011, abstract id: V31B-2525 
Mahoney BA, Shelden KEW (2000) Harvest history of belugas, Delphinapterus leucas, in Cook Inlet, Alaska. Mar Fish Rev 62:124-133

Marcoux M, McMeans BC, Fisk AT, Ferguson SH (2012) Composition and temporal variation in the diet of beluga whales, derived from stable isotopes. Mar Ecol Prog Ser 471:283-291

Matheus PE (1997) Paleoecology and ecomorphology of the giant short-faced bear in eastern Beringia. PhD thesis, University of Alaska Fairbanks

Matthews CJD, Ferguson SH (2015) Weaning age variation in beluga whales (Delphinapterus leucas). J Mammal 96: 425-437

Misarti N, Finney B, Maschnerb H, Wooller MJ (2009) Changes in northeast Pacific marine ecosystems over 4,500 years: evidence from stable isotope analysis of bone collagen from archaeological middens. Holocene 20:151-157

Moore SE, Shelden KEW, Litzky LK, Mahoney BA, Rugh DJ (2000) Beluga, Delphinapterus leucas, habitat associations in Cook Inlet, Alaska. Mar Fish Rev 62:60-80

* Nakagawa S, Schielzeth H (2013) A general and simple method for obtaining $\mathrm{R}^{2}$ from generalized linear mixedeffects models. Methods Ecol Evol 4:133-142

Newsome SD, Etnier MA, Monson DH, Fogel ML (2009) Retrospective characterization of ontogenetic shifts in killer whale diets via $\delta^{13} \mathrm{C}$ and $\delta^{15} \mathrm{~N}$ analysis of teeth. Mar Ecol Prog Ser 374:229-242

Newsome SD, Clementz MT, Koch PL (2010) Using stable isotope biogeochemistry to study marine mammal ecology. Mar Mamm Sci 26:509-572

NMFS (National Marine Fisheries Service) (2016) Recovery plan for the Cook Inlet beluga whale (Delphinapterus leucas). National Marine Fisheries Service, Alaska Region, Protected Resources Division, Juneau, AK

NOAA (National Oceanic and Atmospheric Administration) (2000) Designating the Cook Inlet, Alaska, stock of beluga whale as depleted under the Marine Mammal Protection Act (MMPA). Fed Regist 65:34590-34597

NOAA (2008) Endangered and threatened species: endangered status for the Cook Inlet beluga whale. Fed Regist 73:62919-62930

NOAA (2011) Endangered and threatened species: designation of critical habitat for Cook Inlet beluga whale. Fed Regist 76:20179-20214

O'Corry-Crowe GE, Dizon AE, Suydam RS, Lowry LF (2002) Molecular genetic studies of population structure and movement patterns in migratory species: the beluga whale, Delphinapterus leucas, in the western nearctic. In: Pfeiffer CJ (ed) Molecular and cell biology of marine mammals. Krieger Publishing Company, Malabar, FL, p 53-64

Overland J, Rodionov S, Minobe S, Bond N (2008) North Pacific regime shifts: definitions, issues and recent transitions. Prog Oceanogr 77:92-102

Padilla AJ, Brown RJ, Wooller MJ (2015) Strontium isotope analyses $\left({ }^{87} \mathrm{Sr} /{ }^{86} \mathrm{Sr}\right)$ of otoliths from anadromous Bering cisco (Coregonus laurettae) to determine stock composition. ICES J Mar Sci 72:2110-2117

Peterson BJ, Fry B (1987) Stable isotopes in ecosystem studies. Annu Rev Ecol Syst 18:293-320

Post DM (2002) Using stable isotopes to estimate trophic

Editorial responsibility: Clive McMahon,

Hobart, Tasmania, Australia position: models, methods, and assumptions. Ecology 83: 703-718

* Quakenbush LT, Suydam RS, Bryan AL, Lowry LF, Frost KJ, Mahoney BA (2015) Diet of beluga whales, Delphinapterus leucas, in Alaska from stomach contents, March-November. Mar Fish Rev 77:70-84

R Core Team (2017) R: a language and environment for statistical computing. https://www.R-project.org/

* Rioux È, Lesage V, Postma L, Pelletier É and others (2012) Use of stable isotopes and trace elements to determine harvest composition and wintering assemblages of belugas at a contemporary ecological scale. Endang Species Res 18:179-191

Rugh DJ, Shelden KEW, Hobbs RC (2010) Range contraction in a beluga whale population. Endang Species Res 12: 69-75

Schell DM (2000) Declining carrying capacity in the Bering Sea: isotopic evidence from whale baleen. Limnol Oceanogr 45:459-462

Shelden KEW, Goetz KT, Rugh DJ, Calkins DG, Mahoney BA, Hobbs RC (2015) Spatio-temporal changes in beluga whale, Delphinapterus leucas, distribution: results from aerial surveys (1977-2014), opportunistic sightings (1975-2014), and satellite tagging (1999-2003) in Cook Inlet, Alaska. Mar Fish Rev 77:2-31

Shields P, Dupuis A (2017) Upper Cook Inlet Commercial Fisheries Annual Management Report, 2016. Alaska Department of Fish and Game, Division of Commercial Fisheries, Anchorage, AK

Stewart REA, Campana SE, Jones CM, Stewart BE (2006) Bomb radiocarbon dating calibrates beluga (Delphinapterus leucas) age estimates. Can J Zool 84:1840-1852

Sugiura N (1978) Further analysts [sic] of the data by Akaike's information criterion and the finite corrections. Commun Stat Theory Methods 7:13-26

*Tatsch ACC, Secchi ER, Botta S (2016) Effects of acidification, lipid removal and mathematical normalization on carbon and nitrogen stable isotope compositions in beaked whale (Ziphiidae) bone. Rapid Commun Mass Spectrom 30:460-466

Tieszen LL, Boutton TW, Tesdah KG, Slade NA (1983) Fractionation and turnover of stable carbon isotopes in animal tissues: implications for $\delta^{13} \mathrm{C}$ analysis of diet. Oecologia $57: 32-37$

* Veizer J (1989) Strontium isotopes in seawater through time. Annu Rev Earth Planet Sci 17:141-167

Vos DJ (2003) Cook Inlet beluga age and growth. MSc thesis, Alaska Pacific University, Anchorage, AK

Waugh DA, Suydam R, Ortiz JD, Thewissen JGM (2018) Validation of growth layer group (GLG) depositional rate using daily incremental growth lines in the dentin of belugas (Delphinapterus leucas (Pallas, 1776)) teeth. PLOS ONE 13:e0190498

*Witteveen BH, Worthy GAJ, Foy RJ, Wynne KM (2012) Modeling the diet of humpback whales: an approach using stable carbon and nitrogen isotopes in a Bayesian mixing model. Mar Mamm Sci 28:E233-E250

* Yamaguchi YT, McCarthy MD (2017) Sources and transformation of dissolved and particulate organic nitrogen in the North Pacific Subtropical Gyre indicated by compound-specific $\delta^{15} \mathrm{~N}$ analysis of amino acids. Geochim Cosmochim Acta 22:329-347

Submitted: May 23, 2017; Accepted: March 20, 2018

Proofs received from author(s): May 12, 2018 